\title{
THE PROBLEM OF SOCIAL EFFICIENCY. INDICATORS FOR SOCIAL EFFICIENCY
}

\author{
Venelin Terziev \\ Academician of the Russian Academy of Natural History, Moscow, Russia, Prof. D.Sc. (Ec.), D.Sc. \\ (National Security), D.Sc. (Social Activities), Ph.D., National Military University, Veliko Tarnovo, \\ Bulgaria; University of Rousse, Rousse, Bulgaria, terziev@skmat.com
}

\begin{abstract}
The paper examines some of the most important criteria and indicators for social efficiency. Fundamental ideas of the Bulgarian and foreign economic science for the specifics of social efficiency in the activity of the subjects of institutional governance, including the bodies of state power are discussed. The paper applies a comprehensive (interdisciplinary) approach suggesting integration of sociological, theoretical and management, socio-economic and other aspects of the study is related to the system analysis. The social governance is seen from the perspective of a system method, being the regulation of the relations between the subject and object of management as a purposeful impact on the social system in order to bring its operation and development in accordance with socially significant goals.
\end{abstract}

Keywords: social policy, social program, social efficiency.

\section{INTRODUCTION}

Some experience has been gained in the foreign practice in the measurement of social efficiency within the estimates of the social consequences of scientific and technological projects, economic and social programs. That is how in the USA in the early 70-s a self-direction of research has been established for assessing the social impacts (Social Impact Assessment, abbreviated as SIA), or more precisely the integrated social consequences in the implementation of various projects and programs for development. Business and political circles in the United States realized that every technological breakthrough brings unexpected losses of environmental, social and psychological character, which in turn ultimately lead to indirect economic loss. In the field of scientific and technological development - both at the level of companies and the level of national programs, a reconstruction has started of the entire methodology for planning and management. Earlier it has been oriented only to purely economic efficiency criteria, but now the social, psychological and other consequences of the implementation of scien tific and technical projects started being considered at the stage of taking a decision for their development and implementation. There is a need for comprehensive assessment of the different categories of impact of the equipment and technology on society.

The assessment of the social impact of scientific and technical projects and programs in the USA has been 
separated in a different direction shortly after the adoption of an Act for a policy towards the surrounding environment in 1969 that fixed the mandatory procedure for assessment of their environmental impacts. All government projects that may significantly affect the environment undergo an environmental expertise, as well as the projects of private companies and companies requiring special state sanction. An impressive example of the use of environmental regulations in the implementation of economic development programs in the United States is the organization and development of the project for a pipeline in Alaska in the mid 1970 -s. The project planning is carried out throughout the entire period of construction, operation and dismantling of the pipeline after depletion of the deposit. It should be noted that the entire complex multistep mechanism for the management of the program is formed and functioned on the basis of the active US economic law and special legislative decrees and agreements. This determines the specific form of this control mechanism in which the various parts and components provided by public authorities, owner companies, specialized companies, are related to each other in a single organizational system of bilateral and multilateral agreements and contracts. From the perspective of long-term interests of the nation, the project is recognized as highly efficient and exemplary.

For a long time, the very formulation of the problem of social efficiency has been considered in sociology for arguable. Up to this moment, there is no universally accepted definition of «social efficiency». There are enough works of monographic character, in which the authors try to explore the social effectiveness of the different activities, including management activities. Above all, most authors develop the concept of social efficiency, the criteria and methods for its assessment against the aims of social production. The monograph of the Bulgarian scientist M. Markov is considered as classical work on the issue of social efficiency. He uses the term «efficient» in the strict sense of the word: efficient is what leads to the result, to the effect (in Latin effectus means action, implementation, and afficio means to act, execute) - efficient means actual.

\section{SOCIAL IMPACT AND SOCIAL EFFICIENCY}

In a number of works, primarily the content of the notions of «social impact» and «social efficiency» has been considered. As a rule, the authors of publications agree that the social effect is a certain social result, goal-setting activity that has been made within the life of national economic decisions.

Moreover, in one case it is perceived as «something related to human development», which «forms new features in the image of life and activity, both individual and collective, gives evidence of increasing social activity, contributing to a comprehensive personal development and the formation of a new type of worker». In another case - as «a result, meeting the goals of social progress». In a third case - as a «degree for improving the social and psychological or hygiene comfort of the person».

The proposed definitions allow capturing the essential differences between the concepts of «social impact» and «social efficiency». In the first, a statement for reaching a qualitatively or quantitatively evaluated result of social action in an independent meaning, is reflected and in the second one, the correspondence of this outcome with the measure or degree of realization of the normatively set goal or ideal for public development. This measure for assessing a social effect in turn serves as an important indication of this qualitative side of social activity that is integrated into its system organization thanks to which it essentially reaches the very social efficiency. This inherent efficiency of the social activity, the constitutive qualitative characteristics can be defined as a principle of social efficiency. It is directly related to the criteria for social efficiency as specific quality attributes and determinants of meanings on the basis of which as a kind of «zero points for rendering account» - the social activity is assessed as effective or ineffective. Considering the features that distinguish the social efficiency from the outcome, it is related to either the aims or needs. They note that «the most effective in other equal conditions will be an activity in which the goal to a maximum degree depicts human needs». Along with that, the issue of the specific social outcomes (effects) of the management impact has not been placed, although it is presented in a context that is very significant. The fact is that the setting of the issue for assessment of the social efficiency and the content of this concept is inseparable from the specific analysis as normative or ideological set goals of the social development as well the needs (expectations, interests, ideals) of various social actors.

It seems that social efficiency cannot be considered within the categories of the abstract social prosperity or just as a movement of the social system to some generalized goal of social development.

The social subject (subject of management), which refers to the concept of social efficiency is complicated enough in its structure: it covers the whole range of existing social relations and public relations, and the aims for social control inevitably affect the entire «space» of these connections and relations, including the social system (the society) in general, the social groups (communities) and individuals (people). Based on this and the efficiency of the social management activities, it is necessary to think on the overall assessment for the development of aspects and components of the social system. 
It is obvious that the above examined reference of the efficient social activity to the objectives of the social progress indicates one of the important moments of social connection and interdependence between the general, social-group and individual-personal dimensions of the social activity in the complete and as a rule long lasting nature of its manifestation.

Discussing the socio-economic efficiency of the aimed complex programs, it is found that «the main purpose of the statements and assessment of social efficiency within the program-target method is the basis of the received planning and management decisions». Considering the need to anticipate the social consequences of economic events that are required to be reported in the overall evaluation of their efficiency, a number of authors note that in order to do that «sustainable or quantitative (albeit in a row) dependencies between manufacturing and technical and social changes between the characteristics of planned events and indicators reflecting the corresponding target norms», must be revealed.

Some people associate social efficiency of economy (production) with the problem of efficiency. In sociology, even the question of the legality of a concept like «social efficiency» (in contrast to the more or less clear economic maximum production at minimum costs) appears to be arguable.

Sociologists, who consider this concept as lawful, try to give it a more specific definition. In particular, the criterion of social efficiency is a way to solve social problems in minimum time and minimum costs to society. This definition brings discussions, because the development of criteria for social optimality would significantly move ahead the understanding of the criterion of social efficiency, whatever the final wording of this concept.

In our opinion, the formulation of the question for optimality of the social activity as an integral criterion for its performance is very promising precisely because of the complexity of any social object, its dependence on a number of variables, but also by the presence of internal systematic contradictions.

Optimization in the mathematical theory of optimal processes is the process for selecting the best option possible, bringing the system and the subject in the best possible (optimal) condition; a process which maximizes the quantity characteristic of the most desirable properties of the subject and minimizes the least desirable.

An important theoretical result of the development of the problem of optimization of the national economy is the issue of criteria for optimality (optimum). In general terms, the criteria for optimality in the economy are defined as special economic-mathematical models expressing public aspirations, i.e. as a special variety of formalization of the purposes of economic development in the form of analytic (and therefore a priori set) function.

arguable. Some economists actually identify them as the same thing, while others try to separate these concepts and in this area, there is a lot of focused research work to be done. For now, one thing is clear: there is a close connection between the criteria for optimality and efficiency, and this theoretical intelligibility in the given in relation allows us to achieve considerable success in the objective assessment of the consequences of the implementation of the plans, programs, projects and solutions. It is obvious that such social efficiency can be thought as closely pragmatic - as the best result in solving of an urgent social problem and within the broader social approach reporting strategic and long-term consequences of the measures taken.

Certain contradictions and discrepancies may arise between these approaches. In these conditions, the task for reaching the aggregate social efficiency shall be formulated primarily as a task for optimization of the social managerial activity.

Social and economic efficiency has a twofold aspect: for each executor of a certain type of labor it refers to as part of the common, immediate public work. In terms of the product that is the result of any given type of labor, it exhibits as a quality (property) able to satisfy the increasing demand.

The economic efficiency concerns its criteria for evaluating the results of labor to deciding how much does it cost us to reach the received effect on the social activity, to whom and how this effect serves. Proceeding from this, it can be assumed that unlike the criterion of economic efficiency, the criterion certifying social efficiency does not only change within the "closed» system of social action but has ideal character defined by external normative way. This greatly complicates the assessment of the social efficiency of each management institute, as far it compels it to hold in its visual field the «internal environment» of its activities as in this way the productivity of research can be correctly assessed and measured exclusively with the quality of the given socio-management system, as well as the "external environment», which is not in the sphere of its control, but is the task of normative legal purposes which displays the integrated assessment of social performance. 
It is appropriate to highlight the difference and the relationship between the categories of «efficiency» and «quality». The efficiency criterion is the ratio between cost and result and the quality criterion is the ratio between the effect and purpose, goals and means for their attainment. The principle of efficiency is: less cost and greater results. The principle of quality is the highest degree of achieving the objective in rational (optimal) use of the available resources. It is obvious that in such a formulation the principle of social efficiency should be considered mostly from the standpoint of quality of the social activity and not from the ratio cost-performance.

The problems of social efficiency from operation are paid immediate special attention in the specific management. The given context for our research is the most important and may be too extensive and diverse.

For example, the mentioned by us American Social Impact Assessment - SIA concerns the social consequences of managerial activity in the broadest sense of the word. American authors assign to them in the narrow sense of the word the economic, political, cultural and psychological effects. From the perspective of one who is subjected to impact, we can distinguish social entities and organizations. Social entities are public, social groups, social and territorial communities and individuals. From organizational and institutional perspective, the effects are analyzed to which the activities of the management bodies, ministries, industries, corporations are subjected. From the perspective of the dimensional scale of the impact, the consequences for the country, region, district, municipal, territorial unit - the population of the impacted site are evaluated.

Under the social impact in the strict sense of the word, it is understood the impact on employment, creating new jobs, education and training, self-education, health and quality of life, communication in social groups and between social groups, social cohesion and social segregation within the local territorial community. In this case, the task consists in answering the question of who is winning and who is losing if the alleged act takes place and what the social costs, benefits would be, and how they would be allocated.

In order to give an assessment of the social impact of the management decisions, it is necessary to have criteria that allow us to classify the social consequences to the benefits or costs. In other words, the presence of certain standards and value orientations is assumed.

In fact, the procedure ends with the determination of what some authors call «target» and «necessity» efficiency - which is efficiency, understood in a normative and ideal dimension.

\section{THE PROBLEM OF SOCIAL EFFICIENCY}

The described experience allows us to realize a number of simple truths, without consideration of which we cannot proceed to the creation of socially significant programs and projects, namely:

- Before proceeding to the implementation of any management decision, it is necessary to assess its social meaning, and hence its effectiveness;

- There are no universal standards for social performance as any particular managerial decision must be accompanied by justification of its intended social effect and specific criteria for its evaluation;

- Interpretation of social impact depends on the scale of the management decision, the level of examination of the subjects experiencing the effects of the invention, the motives and objectives pursued, and also on the time interval over which it is expected to get the expected result;

- It is important to distinguish social effect in the broad and narrow sense, considering that there is interdependence between them. Justification of management decisions is increased, if the notion of social impact brings a complex character and incorporates economic, social, psychological, socio-cultural and other significant consequences;

- When evaluating the alleged social impact, it is necessary to navigate to specific value standards, enabling us to judge in a well thought manner for the social «value» of the significant social "continuity of decisions». Such an assessment is possible only in case of comparing the expected social impact of several alternative solutions.

The problem of the social efficiency of management began to actively being explored in the late $60 \mathrm{~s}$ and early $70 \mathrm{~s}$. Before that, it is associated with the development of the theory of social control, which raises the question not only about the economic, but also the social impact of management activity. The question of the efficiency of the management system (efficiency of the operation of the entity's operations management or the management subsystem) is necessary to focus on the following issues: What is the contribution of the management system in solving the socially important tasks? What is its contribution to achieving the 
objectives facing a particular organization?

A primary criterion is the degree of influence of the managed subsystem. However, as far as the management system is relatively independent and functions as a whole complex, another set of criteria can and should be defined. It is formulated based on the primary criterion and answers questions related to the internal state of the management system, with its ability to act with ever-increasing efficiency. Along with the assessment of the efficiency of the management system in the general aspect, the effectiveness of the main components of management - functions, functional structures, technologies might and should be determined.

Efficiency can be seen not only as a phenomenon of the economic sphere, but it is a relatively independent social phenomenon. In its base, it is the consideration of the multilevel structure of the elements, value criteria and indicators. They fix the productivity of social programs and events, the activities of the various population groups, the social consequences of the realization of economic, scientific and technical projects. Social efficiency indicators are considered as tools for assessing the implementation of the interests and needs of society, the state, the group and the individual.

Efficiency as a social phenomenon appears in the form of qualitative and quantitative characteristics for maximum development of the human resources, forms of social vitality and management of society, when taking into account the minimum social, political, economic and moral costs. This approach allows us to consider social performance as a universal means for stating the level of productivity of the positive and negative performance in the development of social institutions and processes. In addition, the widely approved principle of social efficiency goes beyond the given ratio, as it takes into account and integrates several of the most important dimensions of the efficiency of the social activity - its focus on reaching socially significant, legally set targets for development of the site for social management, assessment of the consistency and the actual degree of approximation to the public ideal within the «self-development» of the system and orientation to the quality of managerial activity. These aspects of measuring social efficiency shall naturally be reflected in the construction of the overall model (principle) of social efficiency.

The analysis of the problem of social performance shows that in the process of emergence and development of native and foreign sociology, it naturally receives more attention in the context of different management systems. In particular, the importance of this context in terms of a system for state and regional management of the social aspects of society should be emphasized. The public nature of these systems implies limiting them in their work for social impact and its determining quality of social efficiency in the broad range of social needs and goals. Therefore, the social efficiency of the state management system objectively requires polymodal and multiparameter approach for its measurement. Significant is also the relationship of the complex of social and efficient management with the social security of the country as a whole, as well as with each separate region and territory.

Given the specificity of this study and when speaking on the complex assessment of the efficiency of social programs, the following should be noted: The assessment of the efficiency of social programs should be seen within the section the quantitative and qualitative indicators:

- The quantitative indicator is expressed in the natural volume of social benefits, but also in the material costs for their acquisition;

- The qualitative indicator or criterion is reflected in the internal mechanisms for achieving a certain result (the quality of the organizational and managerial systems, the norms and values, the rules of law on which the activity in a given social system is considered effective or not).

In the assessment of the programs, their economic and social efficiency should also be taken into account. The economic efficiency is evident in the fact that the implementation of the social program is in itself bound to become a catalyst for effective economic development. The means, spend by society to meet social needs, eventually has to be returned in the form of increased social and labor activities. The level for achieving social efficiency, which is determined by the position of the movement to the social ideal that is comprehensively revealed as a state of the most complete realization of human needs and self-realization of their essential strengths, in other words their personality, which is realized before everything in the creation of just living and working conditions. If it turns impossible to calculate the cost-effectiveness, the optimality shall carry more weight in reaching the social impact.

The results from the programs relate either to the objectives of the creators of the program, or to the needs of those to whom these programs are directed. To the greatest extent, efficiency in this case is reached by these programs, in which the objectives of the leaders and organizers of the program fully reflect the needs of the subjects of the program.

Due to the extreme complexity in reporting and evaluation of strategic and long-term consequences of the 
social events within the broader social approach in determining the social efficiency, in this work we will examine the social efficiency of implemented state programs in closely practical terms: as the highest productivity at solving a particular social problem. Evaluating the efficiency of social programs in this case is brought to the task of optimization of social management activities in the process of solving specific social programs by the program approach.

Efficiency criteria of social activity are determined by the objectives and tasks for providing social services to the population and the degree of their implementation. The following points are generally important: the purpose of the social work can be seen at the level of society, individual regions, populated areas, regions and micro-regions, and at the level of population groups and individuals

Efficiency criteria for social activity need to become in the first place an expression of efficiency of all types, forms and methods for social services to the population and in the second place - they must show how effective the administration and social services are in modern Bulgarian conditions relating with the implementation of large and complex reforms. In the third place - criteria and indicators should reflect the degree of efficiency of the management of the entire process of deliberate and systematic social work with the population and the individuals in need of professional social assistance.

Several approaches can be formulated to determine the efficiency of the realized social program. The first will be connected with the most objective assessment of the ratio between the results achieved (effect) and the related costs. A key issue in this case becomes the measuring (description) of the results (effects), and the costs. Given that the cost can be estimated, planned, the efficiency of social services can be estimated, planned, and factual (actually reached).

Another approach focuses on the assessment of the efficiency of the social work from the standpoint of determining the degree of satisfaction of social needs and the expectations of the clients served (users, beneficiaries of the project or program). Critical significance in this case is carried by the subjective assessment methods, i.e. opinions, judgments, speeches (on someone, something that is more or less specific), the particular subject which makes the assessment for the efficiency of the social work. Therefore, in this case it is particularly important to identify and choose the information source of assessment (managers, professionals, representatives of bodies, users etc.) or in other words the subject, carrying important assessment information. Of course, it should be taken into account that assessment information derived from specific people was, is and will be subjective. The more entities there are in the assessment process, the greater the degree (the other conditions being equal) that such an assessment will aim to finding an objective and truthful picture of the activities of the social services and the implementation of the specific social employment program (project).

The complex character of the assessment implies purposeful organization of the process of disclosure of opinions, reasoning and inference voiced by certain forms and methods. In this case, we are dealing with the procedural and organizational significance of the term «assessment of the efficiency of social services». If we want to assess something or someone, it is necessary to organize the assessment process (collection and processing of assessment information), production and use of certain assessment procedures (including for example, complex methods for verification of assessments).

The diversity of assessments, derived from various entities, going through certain procedures and stages in the assessment process, turns into resultant (final) assessments. As a rule, the organizational assessment process of the final information can be the basis of certain important practical conclusions for the implementation of relevant events and actions, development of programs to increase efficiency.

Before the start of the practical measuring of the efficiency of social activity, the researchers inevitably face a number of questions, which they must answer: what is the object of assessment, what is the subject of assessment, what may be a subject to assessment, what is the set of criteria and indicators for assessment, etc.

Efficiency is a summarized, integral indicator of the quality of the system. It is determined by the intrinsic properties of the system (the meanings of the different indicators characterizing the potential and resources), and the conditions in which a given system operates. Therefore, it is more accurate not to talk about efficiency in general, but about the efficiency of the functioning of the system in the performance of specific tasks in certain conditions. There is an opportunity to connect functionally all private quality indicators into a common, integral indicator for efficiency. The study of the quality of this type allows bypassing many difficulties arising in the analysis of complex systems.

Among the factors that allow formulating the objectives and tasks for assessment of the efficiency of social services, we will list the following: 
- The analytical capabilities of the social service of employment in identification and assessment of «inquiries»;

- The resources of the social service of employment in the operational execution of «requests»;

- The potential of the social service of employment (including the level of interaction with government, civil, commercial and public organizations);

- The socio-economic conditions in the administrative territory in which the social service of employment operates; - the qualifications of the staff of the social service of employment; - special care in assessing the efficiency must be paid to the special problem of quality assessment.

Indeed, many issues are solved in the light of quality and indicators (experts) appear to be the subjects for management of the activities of the social service of employment and the objects of its activity. The most typical operation in quality assessment is ranking. We call the objects (phenomena, processes) ranked if any of their quantified changes are in accordance with the specified quality which they possess in varying degrees. In the practice of the various social services of employment, ranking can be used in different situations. The most typical ones are represented by the arrangement of the objects (processes phenomena) in terms of their placement in space and time, in accordance with the level of expression of a quality which cannot be measured by any objective scale, according to some measurable or liable to reporting features (as a rule the degree of expression of a quality, according to which ranking takes place can always be practically measured), in compliance with a quality that is generally measurable, but at the time cannot be measured for practical or theoretical reasons.

Typical example in the use of expertise in management is the developed matrix - «goal: means». The boxes of this matrix shall finally be filled with information derived from the results given by expert assessments.

The methods for efficiency assessment in the social protection system are very diverse, which is determined primarily by the subject for assessment. We will call these methods «first row». Each subject for assessment may be more detailed and then accordingly there will be new methods from the «second row». Every kind of social services (social, household, medical, legal, rehabilitation, psychological, advisory, material assistance) corresponds to a specific methodology for assessing efficiency (Terziev, Georgiev, 2018 a-h, Terziev, Banabakova, Georgiev, 2018i-t, Terziev, 2018u-y).

\section{CONCLUSION}

The problem of studying the efficiency is one of the key areas of various activities of society, especially in production and management. Traditionally, the focus is on economic efficiency, reduced to simple enough and calculated "costresult» ratio. This is a fundamental principle, characterizing the concept of «economic efficiency». Social efficiency does not have so direct character. It is rather a more complex category and is difficult to express in one dimension. Certain contradictions and discrepancies may arise between different approaches and the task for reaching the aggregate social efficiency shall be formulated primarily as a task for optimization of the social managerial activity.

\section{REFERENCE LIST}

Terziev, V., Georgiev, M. (2018a). A strategic framework for the development of social entrepreneurship in Bulgaria. // Knowledge - International Journal, August 2018, Institute of Knowledge Management, Skopje, Macedonia, 25, 2018, N1, pp. 23-34, ISSN 1857-923X (for e-version), ISSN 2545 - 4439 (for printed version).

Terziev, V., Georgiev, M. (2018b). Support for the development of social entrepreneurship in Bulgaria. // Knowledge - International Journal, September 2018, Institute of Knowledge Management, Skopje, Macedonia, 26, 2018, N1, pp.57-74, ISSN 1857-923X (for e-version), ISSN 2545 - 4439 (for printed version).

Terziev, V., Georgiev, M. (2018c). Sotsialna zashtita na uyazvimite grupi ot naselenieto v Balgariya. // Sbornik dokladi ot Godishna universitetska nauchna konferentsiya 14-15 yuni 2018g., Nauchno napravlenie „Sotsialni, stopanski i pravni nauki”, NVU Veliko Tarnovo, Veliko Tarnovo, Izdatelski kompleks na NVU „Vasil Levski”, 7, 2018, str. 188-193, ISBN 978-619-7246-20-9 (online e-book), ISSN 1314-1937. (Терзиев, В., Георгиев, М. Социална защита на уязвимите групи от населението в България. // Сборник доклади от Годишна университетска научна конференция 
14-15 юни 2018г., Научно направление „Социални, стопански и правни науки”, НВУ Велико Търново, Велико Търново, Издателски комплекс на НВУ „Васил Левски”, 7, 2018, стр. 188-193, ISBN 978-619-7246-20-9 (online e-book), ISSN 1314-1937).

Terziev, V., Georgiev, M. (2018d). Podhodi pri obuchenie v organizatsiyata. // Sbornik dokladi ot godishna universitetska nauchna konferentsiya 14-15 yuni 2018 g., Elektronno izdanie, NVU Vasil LevskiVeliko Tarnovo, Veliko Tarnovo, 2018, str. 951-958, ISBN 978-619-7246-20-9 (online e-book), ISSN 2367-7481 (Терзиев, В., Георгиев, М. Подходи при обучение в организацията. // Сборник доклади от годишна университетска научна конференция 14-15 юни 2018 г., Електронно издание, НВУ Васил Левски- Велико Търново, Велико Търново, 2018, стр. 951-958, ISBN 978619-7246-20-9 (online e-book), ISSN 2367-7481).

Terziev, V., Georgiev, M. (2018e). Harakteristiki na sistemata za sotsialno podpomagane. // Sbornik dokladi ot godishna universitetska nauchna konferentsiya 14-15 yuni 2018 g., Elektronno izdanie, NVU Vasil Levski- Veliko Tarnovo, Veliko Tarnovo, 2018, str. 959-969, ISBN 978-619-7246-20-9 (online e-book), ISSN 2367-7481 (Терзиев, В., Георгиев, М. Характеристики на системата за социално подпомагане. // Сборник доклади от годишна университетска научна конференция 14-15 юни 2018 г., Електронно издание, НВУ Васил Левски- Велико Търново, Велико Търново, 2018, стр. 959-969, ISBN 978-619-7246-20-9 (online e-book), ISSN 2367-7481).

Terziev, V., Georgiev, M. (2018f). Sotsialna zashtita na uyazvimite grupi ot naselenieto v Balgariya. // Sbornik dokladi ot godishna universitetska nauchna konferentsiya 14-15 yuni 2018 g., Elektronno izdanie, NVU Vasil Levski- Veliko Tarnovo, Veliko Tarnovo, 2018, str. 970-975, ISBN 978-619-724620-9 (online e-book), ISSN 2367-7481 (Терзиев, В., Георгиев, М. Социална защита на уязвимите групи от населението в България. // Сборник доклади от годишна университетска научна конфреренция 14-15 юни 2018 г., Електронно издание, НВУ Васил Левски- Велико Търново, Велико Търново, 2018, стр. 970-975, ISBN 978-619-7246-20-9 (online e-book), ISSN 2367-7481).

Terziev, V., Georgiev, M. (2018g). Podhodi pri obuchenie v organizatsiyata. // Sbornik dokladi ot Godishna universitetska nauchna konferentsiya 14-15 yuni 2018g., Nauchno napravlenie „Sotsialni, stopanski i pravni nauki”, NVU Veliko Tarnovo, Veliko Tarnovo, Izdatelski kompleks na NVU „Vasil Levski”, 7, 2018, str. 169-176, ISBN 978-619-7246-20-9 (online e-book), ISSN 1314-1937 (Терзиев, В., Георгиев, М. Подходи при обучение в организацията. // Сборник доклади от Годишна университетска научна конфреренция 14-15 юни 2018г., Научно направление „Социални, стопански и правни науки", НВУ Велико Търново, Велико Търново, Издателски комплекс на НВУ „Васил Левски”, 7, 2018, стр. 169-176, ISBN 978-619-7246-20-9 (online e-book), ISSN 1314-1937).

Terziev, V., Georgiev, M. (2018h). Harakteristiki na sistemata za sotsialno podpomagane. // Sbornik dokladi ot Godishna universitetska nauchna konferentsiya 14-15 yuni 2018g., Nauchno napravlenie „Sotsialni, stopanski i pravni nauki”, NVU Veliko Tarnovo, Veliko Tarnovo, Izdatelski kompleks na NVU „Vasil Levski”, 7, 2018, str. 177-187, ISBN 978-619-7246-20-9 (online e-book), ISSN 1314-1937. (Терзиев, В., Георгиев, М. Характеристики на системата за социално подпомагане. // Сборник доклади от Годишна университетска научна конференция 14-15 юни 2018г., Научно направление „Социални, стопански и правни науки”, НВУ Велико Търново, Велико Търново, Издателски комплекс на НВУ „Васил Левски”, 7, 2018, стр. 177-187, ISBN 978-619-7246-20-9 (online e-book), ISSN 1314-1937).

Terziev, V., Banabakova, V., Georgiev, M. (2018i). Modern dimensions of social policies. // International journal scientific papers Vol 23.4 Promoted in Budva, Montenegro 24-27.05.2018, IKM - Skopje, 23, 2018, N 4, pp. 935-944, ISSN 1857-923X (for e-version) ISSN 2545- 4439 (for printed version).

Terziev, V., Banabakova, V., Georgiev, M. (2018j). Social support as part of social policy. // International journal scientific papers Vol 23.4 Promoted in Budva, Montenegro 24-27.05.2018, IKM - Skopje, 23, 2018, N 4, pp. 973-980, ISSN 1857-923X (for e-version) ISSN 2545 - 4439 (for printed version).

Terziev, V., Banabakova, V., Georgiev, M. (2018k). Structure of the social welfare system in Bulgaria. // International journal scientific papers Vol 23.4 Promoted in Budva, Montenegro 24-27.05.2018, IKM Skopje, 23, 2018, N 4, pp. 1275-1281, ISSN 1857-923X (for e-version) ISSN 2545 - 4439 (for printed version).

Terziev, V., Banabakova, V., Georgiev, M. (2018I). Role and place of social programing in public governance. // Mizhnarodnoï naukovo-praktichnoï konferentsiï «Zabezpechennya stalogo rozvitku ekonomiki: problemi, mozhlivosti, perspektivi» (16-17 lyutogo 2018 roku, m. Uzhgorod), Ministerstvo osviti i nauki Ukraïni Uzhgorodsykiy natsionalyniy universitet, 2018, s.93-98, ISBN 978-966-916-488-9. 
(Terziev, V., Banabakova, V., Georgiev, M. Role and place of social programing in public governance. // Міжнародної науково-практичної конференції «Забезпечення сталого розвитку економіки: проблеми, можливості, перспективи» (16-17 лютого 2018 року, м. Ужгород), Міністерство освіти і науки України Ужгородський національний університет, 2018, с.93-98, ISBN 978-966-916-488-9.)

Terziev, V., Banabakova, V., Georgiev, M. (2018m). Social program as a product of social programming. // Mizhnarodnoï naukovo-praktichnoï konferentsiï «Zabezpechennya stalogo rozvitku ekonomiki: problemi, mozhlivosti, perspektivi» (16-17 lyutogo 2018 roku, m. Uzhgorod), Ministerstvo osviti i nauki Ukraïni Uzhgorodsykiy natsionalyniy universitet, 2018, s. 99-104, ISBN 978-966-916-488-9. (Terziev, V., Banabakova, V., Georgiev, M. Social program as a product of social programming. // Міжнародної науково-практичної конференції «Забезпечення сталого розвитку економіки: проблеми, можливості, перспективи» (16-17 лютого 2018 року, м. Ужгород), Міністерство освіти і науки України Ужгородський національний університет, 2018, с. 99-104, ISBN 978-966-916-488-9).

Terziev, V., Banabakova, V., Georgiev, M. (2018n). Social efficiency as a measure of social activities. // Mizhnarodnoï naukovo-praktichnoï konferentsiï «Zabezpechennya stalogo rozvitku ekonomiki: problemi, mozhlivosti, perspektivi» (16-17 lyutogo 2018 roku, m. Uzhgorod), Ministerstvo osviti i nauki Ukraïni Uzhgorodsykiy natsionalyniy universitet, 2018, s. 104-109, ISBN 978-966-916-488-9. (Terziev, V., Banabakova, V., Georgiev, M. Social efficiency as a measure of social activities. // Міжнародної науково-практичної конференції «Забезпечення сталого розвитку економіки: проблеми, можливості, перспективи» (16-17 лютого 2018 року, м. Ужгород), Міністерство освіти і науки України Ужгородський національний університет, 2018, с. 104-109, ISBN 978-966-916-488-9).

Terziev, V., Banabakova, V., Georgiev, M. (20180). Assessment of the effectiveness of social programing. // Mizhnarodnoï naukovo-praktichnoï konferentsiï «Zabezpechennya stalogo rozvitku ekonomiki: problemi, mozhlivosti, perspektivi» (16-17 lyutogo 2018 roku, m. Uzhgorod), Ministerstvo osviti i nauki Ukraïni Uzhgorodsykiy natsionalyniy universitet, 2018, s. 110-115, ISBN 978-966-916-488-9. (Terziev, V., Banabakova, V., Georgiev, M. Assessment of the effectiveness of social programing. // Міжнародної науково-практичної конфреренції «Забезпечення сталого розвитку економіки: проблеми, можливості, перспективи» (16-17 лютого 2018 року, м. Ужгород), Міністерство освіти і науки України Ужгородський національний університет, 2018, с. 110-115, ISBN 978-966-916-4889).

Terziev, V., Banabakova, V., Georgiev, M. (2018p). Social activity of human resource as a basis of effective social policy. // Mizhnarodnoï naukovo-praktichnoï konferentsiï «Zabezpechennya stalogo rozvitku ekonomiki: problemi, mozhlivosti, perspektivi» (16-17 lyutogo 2018 roku, m. Uzhgorod), Ministerstvo osviti i nauki Ukraïni Uzhgorodsykiy natsionalyniy universitet, 2018, s. 116-121, ISBN 978-966-916488-9. (Terziev, V., Banabakova, V., Georgiev, M. Social activity of human resource as a basis of effective social policy. // Міжнародної науково-практичної конфреренції «Забезпечення сталого розвитку економіки: проблеми, можливості, перспективи» (16-17 лютого 2018 року, м. Ужгород), Міністерство освіти і науки України Ужгородський національний університет, 2018, с. 116-121, ISBN 978-966-916-488-9).

Terziev, V., Banabakova, V., Georgiev, M. (2018q). Strategic advantages of an active social program. // Mizhnarodnoï naukovo-praktichnoï konferentsiï «Zabezpechennya stalogo rozvitku ekonomiki: problemi, mozhlivosti, perspektivi» (16-17 lyutogo 2018 roku, m. Uzhgorod), Ministerstvo osviti i nauki Ukraïni Uzhgorodsykiy natsionalyniy universitet, 2018, s. 122-127, ISBN 978-966-916-488-9. (Terziev, V., Banabakova, V., Georgiev, M. Strategic advantages of an active social program. // Міжнародної науково-практичної конференції «Забезпечення сталого розвитку економіки: проблеми, можливості, перспективи» (16-17 лютого 2018 року, м. Ужгород), Міністерство освіти і науки України Ужгородський національний університет, 2018, с. 122-127, ISBN 978-966-916-488-9).

Terziev, V., Banabakova, V., Georgiev, M. (2018r). Assessment of the effectiveness of social programming. // Mizhnarodnoï naukovo-praktichnoï konferentsiï «Zabezpechennya stalogo rozvitku ekonomiki: problemi, mozhlivosti, perspektivi» (16-17 lyutogo 2018 roku, m. Uzhgorod), Ministerstvo osviti i nauki Ukraïni Uzhgorodsykiy natsionalyniy universitet, 2018, s. 127-131, ISBN 978-966-916-488-9. (Terziev, V., Banabakova, V., Georgiev, M. Assessment of the effectiveness of social programming. // Міжнародної науково-практичної конференції «Забезпечення сталого розвитку економіки: проблеми, можливості, перспективи» (16-17 лютого 2018 року, м. Ужгород), Міністерство освіти і науки України Ужгородський національний університет, 2018, с. 127-131, ISBN 978-966-916-4889).

Terziev, V., Banabakova, V., Georgiev, M. (2018s). The social program as a part of development strategies. 
// Mizhnarodnoï naukovo-praktichnoï konferentsiï «Zabezpechennya stalogo rozvitku ekonomiki: problemi, mozhlivosti, perspektivi» (16-17 lyutogo 2018 roku, m. Uzhgorod), Ministerstvo osviti i nauki Ukraïni Uzhgorodsykiy natsionalyniy universitet, 2018, s. 132-137, ISBN 978-966-916-488-9. (Terziev, V., Banabakova, V., Georgiev, M. The social program as a part of development strategies. // Міжнародної науково-практичної конфреренції «Забезпечення сталого розвитку економіки: проблеми, можливості, перспективи» (16-17 лютого 2018 року, м. Ужгород), Міністерство освіти і науки України Ужгородський національний університет, 2018, с. 132-137, ISBN 978-966-916-4889).

Terziev, V., Banabakova, V., Georgiev, M. (2018t). Social programming as a possibility to increase social efficiency. // Mizhnarodnoï naukovo-praktichnoï konferentsiï «Zabezpechennya stalogo rozvitku ekonomiki: problemi, mozhlivosti, perspektivi» (16-17 lyutogo 2018 roku, m. Uzhgorod), Ministerstvo osviti i nauki Ukraïni Uzhgorodsykiy natsionalyniy universitet, 2018, s. 137-142, ISBN 978-966-916488-9. (Terziev, V., Banabakova, V., Georgiev, M. Social programming as a possibility to increase social efficiency. // Міжнародної науково-практичної конференції «Забезпечення сталого розвитку економіки: проблеми, можливості, перспективи» (16-17 лютого 2018 року, м. Ужгород), Міністерство освіти і науки України Ужгородський національний університет, 2018, с. 137-142, ISBN 978-966-916-488-9)

Terziev, Venelin. (2018u). The active model of a social programme and its strategic advantage. // ADVED 2018- 4th International Conference on Advances in Education and Social Sciences Abstracts \& Proceedings, 15-17 October 2018- Istanbul, Turkey, International Organization Center of Academic Research, www.ocerints.org, Istanbul, Turkey, 2018, pp. 189-203, ISBN: 978-605-82433-4-7.

Terziev, Venelin. (2018v). Active social programs development in Bulgaria: contemporary challenges and social management instruments. // ADVED 2018- 4th International Conference on Advances in Education and Social Sciences Abstracts \& Proceedings, 15-17 October 2018- Istanbul, Turkey, International Organization Center of Academic Research, www.ocerints.org, Istanbul, Turkey, 2018, pp. 149-163, ISBN: 978-605-82433-4-7.

Terziev, Venelin. (2018w). Social assistance services and integrated employment in Bulgaria. // ADVED 2018- 4th International Conference on Advances in Education and Social Sciences Abstracts \& Proceedings, 15-17 October 2018- Istanbul, Turkey, International Organization Center of Academic Research, www.ocerints.org, Istanbul, Turkey, 2018, pp. 164-177, ISBN: 978-605-82433-4-7.

Terziev, Venelin. (2018x). Impact of the labor market policies for ensuring employment. // ADVED 2018- 4th International Conference on Advances in Education and Social Sciences Abstracts \& Proceedings, 1517 October 2018- Istanbul, Turkey, International Organization Center of Academic Research, www.ocerints.org, Istanbul, Turkey, 2018, pp. 178-188, ISBN: 978-605-82433-4-7.

Terziev, Venelin. (2018y). Importance of human resources to social development. // ADVED 2018- 4th International Conference on Advances in Education and Social Sciences Abstracts \& Proceedings, 1517 October 2018- Istanbul, Turkey, International Organization Center of Academic Research, www.ocerints.org, Istanbul, Turkey, 2018, pp. 204-212, ISBN: 978-605-82433-4-7. 